\title{
The current state of the private investigation industry in Korea and its legislation process
}

\author{
Chang-Ho Kim, Ju-Lak Lee* \\ Dept. of Security Management, Kyonggi University, Suwon, Korea
}

Email address:

julaklee@hanmail.net(Ju-Lak Lee)

\section{To cite this article:}

Chang-Ho Kim, Ju-Lak Lee. The Current State of the Private Investigation Industry in Korea and Its Legislation Process. Social Sciences. Vol. 2, No. 6, 2013, pp. 195-199. doi: 10.11648/j.ss.20130206.14

\begin{abstract}
The demand for security services in Korea has been on the rise with the increased income of the citizens as well as awareness about individual rights. Two representative sectors that reflect this change is the privatized security and investigation fields of the country. However, the private investigation industry has not been legally authorized, so most employees in this field work for lawyers and support their tasks, or for the "errand centers" and often engage in illegal activities, causing different social issues. In order to resolve this problem, related legislation for legalization of private investigation has been proposed since late 1990s, but due to the privacy issue, conflict with other laws, difficulty in designating the agency in charge of supervising private investigation organizations, etc. have led to recurring abrogation. Despite the challenge, the discussion to legalize private investigation in Korea has recently resurfaced with the new president and her administration. Therefore, the authors in this study examined the current state of the private investigation businesses in Korea and the legalization process in addition to the points at issue.
\end{abstract}

Keywords: Private Investigation, Private Security, Legalization, Privatization of Security Services

\section{Introduction}

As the Korean economy went through rapid development stages over the past few decades, protection of individual lives and property has become the main priority for the citizens, with food, clothing, and shelter taken care of for most people. This change reflects the crimes in the Korean society that have diversified and become more intelligent and violent, as well as the conflicts between groups and organizations that pose a threat to the security of the society. To solve this issue, the public organizations in Korea strive to provide adequate services, including law enforcement and investigation, but their quality is not at a satisfactory level due to limited resources; therefore, an illegal private security industry developed to meet the demand of the citizens who were willing to pay for what they needed [1].

Security and investigation can be considered as the two representative areas of privatization. In Korea, 3,836 private security businesses with 150,030 employees provide services according to the statistics provided by the National Police Agency, which tops 102,386 police officers and proves how developed it is even when compared at an international level [2].

On the other hand, private investigation field has not been legalized and been in operation illegally. Article 3 of the "Attorneys-At-Law Act" prohibits the law-related tasks performed by non-attorneys. Moreover, titles like detective and private investigator cannot be used and the services related to locating whereabouts of individuals and investigating private lives are banned by Article 26 of Use and Protection of the Credit Information Act [3].

The private investigation system is authorized by law in all the countries registered in the Organization for Economic Cooperation Development (OECD) except Korea. Specifically, the private investigators in these nations perform the tasks including collecting stolen properties, gathering evidence for trials, etc. Despite the trend in other OECD countries, national organizations and the police in Korea are not able to handle the issue of missing people effectively because of financial limitation. Also, as the Criminal Procedure Law was revised in 2007, the weight that physical evidence carries in the trials increased substantially, emphasizing the need for implementing an official system that facilitates the information gathering process to meet the increasing demand.

Fortunately, these days, there are ongoing discussions for legalization of private investigation in Korea. The authors, 
therefore, examined the current state of the private investigation industry in Korea and the points at issue for the legislation. The main method of research was an archival research that reviewed existing related literature, and to obtain the information not acquired through the literature review, personal interviews with five current private investigators were conducted.

\section{Concept of Private Investigation}

Definition of private investigation varies by scholar in Korea. For instance, Jeong [4] states that it is the investigation work carried out by individuals and businesses without official certification, and Jo [5] argues that it is an act of information collecting, analyzing, and providing of the information by those employed under a contract. In sum, private investigation indicates provision of fact-finding services by private businesses in return for financial compensation.

When the concept of private investigation was first introduced, the term, "Tamjung"(Private Detective) was used widely; but now the Use and Protection of the Credit Information Act mentioned earlier prohibits the use of the term, and as the errand centers that often engaged in illegal activities (which contributed to creating negative images for private detectives) called themselves as such, the term private investigation is preferred nowadays [6].

\section{Private Security Systems in Major OECD Countries}

\subsection{The United States}

The United States has the most developed private investigation system in the world, and it is utilized very widely throughout the country in numerous cases. The outcome of an American trial heavily depends on whether plausible evidence is presented to the jury with emotional appeal by each side. In this battle of information gathering, an attorney that is only well-informed about the law has difficulty prevailing, so the private investigators have become indispensable cooperators [7].

\subsection{The United Kingdom}

In the United Kingdom, "Private Security Industry Act 2001" which encompassed private investigation and security was enacted in response to the need for the legislation for preventing public crime; and the related regulations took effect in January, 2006 due to the gradual implementation scheme [6]. Article 4 of this law stipulates that the duty of private investigators can include surveillance, search, and investigation for the purpose of collecting individuals' information such as their activities and whereabouts in addition to lost and damaged personal property [8].

\subsection{Japan}

In Japan, to resolve the issues created by illegal private investigation activities, The Law regarding Appropriateness of the Work of Private Detectives was enacted in June 2006 to regulate the leakage of private information, investigation, wiretapping, etc. Article 2 of the law states that private investigation work means providing information related to the location and activities of a certain individual to the requested party using the methods of interview, shadowing, indirect inquiry, and stakeout [9].

\section{Current State of the Private Investigation Business in Korea}

\subsection{Illegal Activities through Inquiry Agencies and Errand Centers}

As socially accepted professionals, the private investigators in foreign countries carry out their inherent functions and duties on a daily basis. Unlike the foreign state, the private investigators in Korea have not been acknowledged and even the usage of their titles is banned by law. Despite the systematic effort for a change, many businesses are still in operation to carry out private investigation in the form of inquiry agencies and errand centers.

In the past Korean society, inquiry agencies mainly engaged in the work of investigating credit-related matters such as commercial transactions, asset, and finance to informing their clients [7]. Unfortunately, as these tasks were carried out in an illegitimate way with the help from gangsters and caused social public criticism, the term "inquiry agency" was gradually replaced by "errand center" in the 1970s while continuing to employ the conventional methods [6].

According to the regulations in effect, errand centers can be classified into the "other service business" category, so anyone can establish one without many restrictions. This makes it difficult to calculate the actual number of errand centers in business and promotes the growth of unregistered agencies and undermines the effectiveness of the government's regulatory capability [10].

Jeong [4] states that there are 2,650 errand centers and inquiry agencies throughout Korea when search by Naver and Daum, the two most popular search engines in the country. Out of all the businesses, 550 are located in Seoul, and it is estimated that up to seventy percent of the total number engage in the work that is similar with private investigation [3].

The usual illegal activities involved include buy over, assault, threat, misrepresentation, fabrication, counterfeit, wiretapping and secret filming, shadowing, theft, burglary, intervention in criminal cases, leakage of private information, illegal debt collection, illegal arrest and confinement, murder by contract, etc.; and despite the grim reality, the law enforcement agencies have had a hard time 
tracking these activities and punish the main actors [5].

In an effort to eradicate the issue, the police cracked down on illegal errand centers throughout the country from January 8 to March 7, 2013 and twenty-four companies were investigated and 137 suspects (six taken into custody) were arrested. Specifically, illegal investigation of one's private life was found be most frequently occurring (sixty-seven percent, sixteen cases), followed by using location tracking device (seventeen percent, four cases), leaking and providing personal information (thirteen percent, three cases), and illegal debt collection (three percent, one case). Despite the endeavor of the Korean police, the illegal activities continue to exist and the manpower of the law enforcement agencies is insufficient for an effective solution [11].

\subsection{Foreign Private Investigation Companies in Korea}

Since joining the OECD in 1996, Korea has opened its private investigation market to foreign companies and around twenty businesses including Kroll, Hill \& Associates (H\&A), and Pinkerton have established domestic branches and provided services for Korean enterprises; and the number of Korean private investigators that work for foreign companies is estimated to be around 400 [12].

The aforementioned Pinkerton, an American company, founded a branch in Korea in the early 2000s and closed their business, but has been in the process of resuming it in recent years. A Hong Kong-based H\&A has been active in Korea since 2004, and another U.S. investigation business, Kroll was in business from 2005 to 2009, and restarted its services in cooperation with Sentinel Korea in 2012. A major reason for these companies to continue to run businesses in or re-enter the Korean market is the dramatic increase in the demand of information security and business risk management market [12].

Korea lacks the manpower to perform business-related investigation due to the absence of related laws, which hinders the growth of the domestic companies and leads to an increase in the number of foreign businesses to satisfy the need of the companies that are getting more globalized [11].

Furthermore, the country has recently signed the Free Trade Agreement (FTA) with the United States and the European Union (EU) and is having discussions with more countries to enter into an agreement; and once FTA is ratified with those countries, a large number of foreign law firms will be able to enter the Korean market, for which many private investigators are expected to be given the duty of examining different facts of a variety of cases.

\section{Bill Propulsion Process}

Although the private investigation industry can contribute to solving many societal security issues, absence of the related legislation has led to promoting illegal activities by the errand centers and the frequent media coverage of the grim reality. In Korea, beginning the proposal submitted by Ha, Soon-Bong in 1999, there has been a total of seven proposals to legislate for private investigation; however, each case was rejected and two new bills are now pending at the National Assembly.

Numerous challenges are present in the process of passing a private investigation law, which include deciding the supervising agency and defining the scope of work a private investigator can perform (Personal Interview, $15^{\text {th }}$ June 2013). The following table provides information about the points at issue.

Table 1. History of private investigation law legislation proposal

\begin{tabular}{|c|c|c|c|}
\hline $\begin{array}{l}\text { Representative } \\
\text { Proposer }\end{array}$ & $\begin{array}{l}\text { Legislation } \\
\text { Title }\end{array}$ & Supervising Agency & Result \\
\hline Ha, S. B. (1999) & Legislative Bill on Official Private Investigator & Commissioner General of KNPA* & Failed before proposal \\
\hline Lee, S. B. (2005) & Legislative Bill on Private Investigation & Commissioner General of KNPA & $\begin{array}{l}\text { Proposed, but repealed due to termination } \\
\text { of the term }\end{array}$ \\
\hline Choi, J. C. (2006) & $\begin{array}{l}\text { Legislative Bill on Private Investigation } \\
\text { Business }\end{array}$ & $\begin{array}{l}\text { Justice } \\
\text { Minister }\end{array}$ & $\begin{array}{l}\text { Proposed, but repealed due to termination } \\
\text { of the term }\end{array}$ \\
\hline Lee, I. K. (2008) & $\begin{array}{l}\text { Legislative Bill on Partial Revision of Security } \\
\text { Business Law }\end{array}$ & Commissioner General of KNPA & $\begin{array}{l}\text { Proposed, but repealed due to termination } \\
\text { of the term }\end{array}$ \\
\hline Kang, S. C. (2009) & $\begin{array}{l}\text { Legislative Bill on Private Investigation } \\
\text { Business }\end{array}$ & $\begin{array}{l}\text { Justice } \\
\text { Minister }\end{array}$ & $\begin{array}{l}\text { Proposed, but repealed due to termination } \\
\text { of the term }\end{array}$ \\
\hline Yoon, J. O. (2012) & $\begin{array}{l}\text { Legislative Bill on Complete Revision of } \\
\text { Security Business Law }\end{array}$ & Commissioner General of KNPA & Currently under review \\
\hline Song, Y. G. (2013) & Legislative Bill on Private Investigation & $\begin{array}{l}\text { Justice } \\
\text { Minister }\end{array}$ & Currently under review \\
\hline
\end{tabular}

*Korean National Police Agency

Source: The National Assembly of the Republic of Korea, Retrieved from http://likms.assembly.go.kr/bill/jsp/main.jsp 


\subsection{Points at Issue Related to the Supervising Agency}

Currently, a main controversy over which agency between the Ministry of Justice and the Korean National Police Agency (KNPA) should be the organization in charge of overseeing the private security businesses in Korea is a reason for repeated failure for legislation attempts in the National Assembly. As can be seen in Table 1 , four of the seven proposals designated the Commissioner General of KNPA as the head supervisor with the other three nominating the minister of the Ministry of Justice for the job.

The arguments supporting the police agency state that the police that is in charge of protecting the security of the citizens on a daily basis and regulate the private security business matters should take the role as the authority. In addition, these supporters also emphasize the fact that the main tasks of private investigation include finding missing

\subsection{Discussion over the Task Scope}

people and examining the causes of victimization, which are closely related to the police duties. Also, they argue that private investigation and security are not divided but are provided in one system in foreign countries, accentuating the police's suitability as a supervising agency [13].

On the other hand, others assert that the major duties of private investigators are more relevant to protecting the rights of citizens and promoting convenience when they need to deal with the law. Therefore, the Ministry Justice that currently directs the prosecutors who manage judicial police officers should also supervise the private security officers and investigators [10]. However, both arguments can be seen as a result of the conflict between the police officers who want to continue their career in the private investigation field and the attorneys that want to maintain their vested rights (Personal Interview, $15^{\text {th }}$ June 2013).

Table 2. Task description proposed by the bills

\begin{tabular}{|c|c|c|}
\hline \multicolumn{3}{|l|}{ Task Description } \\
\hline \multicolumn{3}{|c|}{$\begin{array}{l}\text { (1) Investigating crimes and illegal activities } \\
\text { (2) Locating lost/stolen property } \\
\text { (3) Investigating causes and responsibilities of different types of accident or damage } \\
\text { (4) Acquiring the evidence to be used at trials } \\
\text { (5) Locating missing persons } \\
\text { (6) Investigating other matters designated in the presidential directives }\end{array}$} \\
\hline Bill & Task Scope & Note \\
\hline Ha, S. B. (1999) & (1)(2)(3)(4)(6) & \\
\hline Lee, S. B. (2005) & (1)(2)(3)(4)(5)(6) & (5) Restrict missing persons to family members \\
\hline Choi, J. C. (2006) & (1)(2)(3)(4)(5)(6) & (2) Includes the assets used for evasion \\
\hline Lee, I. K. (2008) & (2)(3)(5) & (5) Restricted to runaways, missing children, and the disappeared \\
\hline Kang, S. C. (2009) & (2)(4)(5) & $\begin{array}{l}\text { (4) Restricted to the cases requested by attorney } \\
\text { (5) Restricted to runaways, missing children, the disappeared, and wrongdoers }\end{array}$ \\
\hline Yoon, J. O. (2012) & (2)(3)(5) & (5) Restricted to runaways, missing children, the disappeared, and wrongdoers \\
\hline Song, Y. G. (2013) & (2)(3)(4)(5) & (4) Restricted to the cases requested by attorney \\
\hline
\end{tabular}

Source: The National Assembly of the Republic of Korea, Retrieved from http://likms.assembly.go.kr/bill/jsp/main.jsp

The consensus seems to have been reached that introduction of private investigation system in Korea is necessary due to the limitation of the public service, the need for legalization of private investigation, and rise in demand. Next challenge is defining the scope of private investigation with different matters such as the perception of the citizens, state of related industries, structural relationship with relevant laws, etc. taken into consideration.

As shown by Table 2 above, more recent proposals tend to restrict the work scope at a stricter degree when compared to the older ones, and this could be analyzed as a way to avoid the anticipated problems of the conflict with other laws and the invasion of privacy as well as leakage of personal information issues that were mentioned in the earlier proposals (personal interview, $23^{\text {rd }}$ June 2013).

Five main task areas of private investigation suggested by the proposals can be categorized into "Investigation of crimes and illegal activities," "Identifying the location of lost and stolen property," "Investigation of the causes and responsibilities of various accidents and damage," "Acquisition of the evidence to be used at trials," and "Locating missing persons." Among the five, locating the lost and stolen property, investigating the causes and responsibilities of different accidents and damage are included in every bill as they are not included in the area of individual privacy and information, thus easily being allowed as private investigation tasks [1].

Although there is a dispute over the scope of finding missing people, whether to extend the task to the 
wrongdoers and to those who have not fulfilled their financial obligations, this is a matter of adopting the self-help principle for the victims of financial damage or rejecting it for protection of their privacy [4].

Despite the fact that investigation of crimes and illegal activities are legalized in the United States and most foreign countries, it is a controversial topic of discussion in Korea. The citizens tend to think of it as the duty of public agencies, and are concerned of the fairness issue in case of the investigation by private sectors and individual organizations [1].

The most controversial issue, out of all, is whether to include evidence acquisition in the work scope of private investigation; and this is a result of the prevalent use of secret recording, wiretapping, shadowing, and break-ins to obtain such evidence and the effort to protect personal information and privacy [14].

\section{Conclusions}

At the moment, the absence of the legislation for private investigation businesses has caused different social problems. Therefore, following the precedents of other countries with the private investigation established as a sector of private security, Korea should also institutionalize private investigation businesses. With the change, the current limitation of national security agencies will be reinforced with an increase in security services, effectiveness of retrieving lost and stolen property and finding missing persons will improve, and job opportunities for experts will grow, which will help promote economic advancement.

With the FTAs with the United States and the European nations agreed upon, the legal industry is also anticipated to be opened to foreign countries; this means foreign law firms and their private investigators will begin their businesses in the country as well. Up until now, domestic law firms generally prepared for their trials without expert investigators, but by solely relying on the evidence provided by the clients. As the difference of having investigators is crucial in carrying out their duties, it is expected that the competitiveness of foreign firms would be superior to that of the domestic businesses, which makes passing of private investigation bills a critical task.

For the past thirteen years, the discussions over legalization of private investigation in Korea have failed repeatedly due to the privacy issue, the conflict with other laws, the problem in the legal structure, and the dispute over deciding the supervising agency [15]. The crime in Korea is increasing each year with its methods becoming more specialized and violent. Furthermore, it is happening more widely throughout the country and the average age of criminals is getting younger. All of these current trends call for a prompt legalization of private investigation and improvement of the current system.

\section{References}

[1] J. V. Choi, J. L. Lee and S. W. Hwang, "Establishing the Work Scope of Private Investigation System”, Korea Journal of Police Studies, vol. 11, no. 1, pp. 225-244, 2012.

[2] Korea National Police Agency, "White Paper on Crime", Seoul: Korea National Police Agency, 2013.

[3] S. G. Jo and T. M. Kim, "A Study on the Establish Direction of the Private Investigation Act", Korea Journal of Police Science, vol. 33, pp. 241-267, 2012.

[4] I. S. Jeong, "Schemes to Adopt the Private Investigation System to Expand the Realm of Private Security", Unpublished Doctoral Dissertation, Yongin University: Yongin, Korea, 2008.

[5] S. G. Jo and D. J. Kim, "The Influence that the Introduction of the Private Investigative Job Affects to the National Public Peace", Korea Journal of Risk Management, vol. 9, no. 2, pp. 33-48, 2013.

[6] D. H. An, "A Study on the Ideal Relationship between Private Investigators and Related Agencies", Unpublished Master's Thesis, Yonsei University: Seoul, Korea, 2007.

[7] Y. S. Kang, T. H. Kim, W. J. Yoo and K. K. Lee, "Introduction to Private Investigation", Jinyoungsa: Incheon, 2009.

[8] Y. R. Lee, "A Suggestion on the Private Investigation Service of Foreign Developed Countries: Centering around Domestic Introduction and the Case of the Operations in the Developed Countries", Korea Journal of Public Security Administration, vol. 5, no. 2, pp. 25-44, 2009.

[9] K. H. Moon, "A Study on the Scope and Limitation of the Private Investigators' Duty under the Revised Security Law", Research on Police Law, vol. 7, no. 1, pp. 129-166, 2009.

[10] Y. S. Kang. "A Study on the Introduction Plan of Licensed Private Investigation Service System in Korea", Unpublished Doctoral Dissertation, Yongin University: Yongin, Korea, 2006.

[11] H. W. Kim, "Enactment of the Legislation on Private Investigation and Development of a Cooperative System with other Investigative Agencies", Unpublished Master's Thesis, Kyonggi University: Suwon, Korea, 2013.

[12] J. S. Kim, "Legalization of Private Investigation Businesses, Time for a Decision", Security News, April $15^{\text {th }} 2013$.

[13] S. H. Chang and B. H. Song, "A Study on the Point at the Issues in Introduction of Private Investigation Industry", Korean Journal of Public Safety and Criminal Justice, vol. 33, pp. 335-365, 2008.

[14] M. H. Lee and Y. N. Song, "A Study on Policy Measures for Introducing Private Investigator Service", Korea Journal of Public Security Administration, vol. 8, no. 1, pp. 265-284, 2011.

[15] S. G. Jo, "A Study on the Introduction of the Private Investigation Awareness of the Police Officers of Korea", Unpublished Doctoral Dissertation, Kyonggi University: Suwon, Korea, 2011. 